\title{
Dynamic Voltage Restorer with New Hybrid Cascade Multilevel Inverter using Fuzzy Controller
}

\author{
Varsha Singh \\ N.I.T Raipur \\ Electrical Engineering \\ Department \\ Raipur, India
}

\author{
S.Gupta \\ N.I.T Raipur \\ Electrical Engineering \\ Department \\ Raipur, India
}

\author{
S.Pattnaik \\ V.N.I.T Nagpur \\ Electrical Engineering \\ Department \\ Nagpur, India
}

\begin{abstract}
Inverters are used in many applications now-a-days. One among the major applications is Dynamic Voltage Restorer (DVR), it is a custom power device to guard sensitive loads against voltage disturbances such as voltage sag and voltage swell, both considered to be important parameters of power quality. This paper attempts to study and analyze the performance of a DVR based on a new 11-level symmetrical multilevel inverter, using minimum required numbers of switches with fuzzy logic controller to compensate voltage sag and swell to regulate the load voltage to the best possible extent. The proposed multilevel inverter topology also reduces the cost and complexity in controlling of inverters.
\end{abstract}

\section{Keywords}

Multilevel Inverter, DVR, Voltage sag, Voltage Swell.

\section{INTRODUCTION}

In modern Industrial setups, several electronic devices are used to enhance production. These electronic devices are susceptible to failure due to sudden change in quality of power supply. Power quality is the set of limits of electrical properties that allows electrical/electronic system to function in their intended manner without significant loss of performance or life. Voltage sags \& voltage swell, poor voltage and frequency regulation, harmonics and switching transients are frequently encountered power quality issues.

Voltage sag is a sudden reduction of utility supply voltage from $90 \%$ to $10 \%$ of its nominal value, whereas, voltage swell is a sudden rise of supply voltage from $110 \%$ to $180 \%$ of its nominal value. The main requirement of any system is to maintain the load side voltage at constant level. Dynamic Voltage Restorer (DVR) provides effective solution to the power quality problems such as voltage sag and voltage swell.[1] DVR is mostly used for Low Voltage (LV) and Medium Voltage (MV) applications. DVR protects a sensitive load from distortions in the supply side during faults or overload in power system by inserting a voltage of required magnitude and frequency; the series compensator can restore the load side voltage to the desired amplitude and waveform even when the source voltage is unbalanced or distorted In LV application generally two level VSI are used and if two level VSI are used in MV application, the switches of VSI must block high voltages. A closed loop control method is used to maintain a constant load voltage in the event of disturbances in supply [2]. In MV applications it is more appropriate to implement DVR with Multilevel VSI to reduces the stress on switches and lower the losses at switches[3][4]. In DVR, Voltage Source Inverter (VSI) is used to generate required amount of voltage to maintain the load voltage at constant level. Recently several multilevel inverter are used in DVR for compensating the voltage sag and swell [5][6]. The main disadvantage of multilevel inverter is that, it requires more numbers of power switches which increases the losses and control complexity of inverter [7][8][9]. Sometimes the output voltage is not limited to DC voltage source similar to traditional cascade multilevel inverter and can be increased with $\mathrm{Z}$ network shoot-through state control [10]. Fuzzy logic controller is implemented in DVR to respond quickly on the request from abruptly changing reference signals [11]. As proposed by authors, (Ramasamy.M et.al.) a fuzzy logic based PV-DVR can be deployed to diminish the power quality problems during peak load and off load hours at distribution system thereby also doing away with the shortcomings of conventional DVR and UPS[12]. The addition of fuzzy logic control to conventional PI control gives added advantage of faster response as compared to the conventional one .The STATCOM, which is a vital device in field of power quality, has several applications such as power factor corrector, harmonic compensator and voltage mitigation [13]. To improve the performance of DVR the fundamental frequency control method is used instead of pulse width modulationbased methods, these results in lowering the switching losses. [14]. By using a ac/ac converter, and eliminating the dc-link, the topology for DVR is further simplified, this topology can be extended to n-phase systems also without compromising the basic principles, to restore voltage sags and swells of both balanced and unbalanced conditions [15]. In this proposed work a fuzzy logic controller to control symmetrical Hybrid Cascade Multilevel inverter with less numbers of power switches is used for DVR to compensate Voltage sag/ swell. Out of the different power quality problem i.e. flicker, transient, harmonic distortion voltage sag/swell the important power quality problems voltage sag/swell are discussed.

Voltage Sag: Definition: According to the IEEE defined standard, IEEE Std. 1159, 1995 Voltage Sag is defined as a decrease of RMS voltage from $10 \%$ and $90 \%$ of nominal, for duration of 0.5 cycles to 1 minute. Decrease in the RMS value of the voltage ranging from a half cycle to a few seconds and voltage sags often caused by starting of large induction motors, energizing a large capacitor bank and faults such as single line to ground fault, three phase to ground fault, double line to ground fault on the power distribution system.

Voltage Swell: Definition: As per IEEE standard, is defined as the increase in the RMS voltage level to $110 \%-180 \%$ of nominal, for durations of 0.5 cycles to 1 minute. Increase in the RMS value of the voltage ranging from a half cycle to a few seconds causes Voltage swells that are usually associated with system faults condition just like voltage sags but are much less common. This is mainly true for ungrounded or floating delta systems, where the sudden change in ground reference results in a voltage rise on the ungrounded phases. In the case of a voltage swell due to a single line to ground (SLG) fault on the system, the result is a temporary voltage rise on the un-faulted phases, which last for the duration of the fault. 


\section{PROPOSED TOPOLOGY}

Figure-1 shows the proposed topology of hybrid cascade multilevel inverter. This topology is formed by connecting the several basic units (b) in series. Basic module consists of two DC sources and one diode and three unidirectional switches. All positive levels of output are generated by Basic Module only so it is also works as level creator. There are three switches $\mathrm{S} 1, \mathrm{~S} 2$ and $\mathrm{S} 3$, the output voltage levels are produced by different combination of these switches. To prevent any short circuit at a time only one switch should be conducted. D1 should be on only when S3 is conducted. To get all levels (positive, negative, zero) requires a H-bridge circuit where there are four switches (T1, T2, T3, T4) and by the different combination of these switches we can get different levels of output. For any multilevel topology it is said to be symmetric when it's all dc sources are having equal value Vdc.

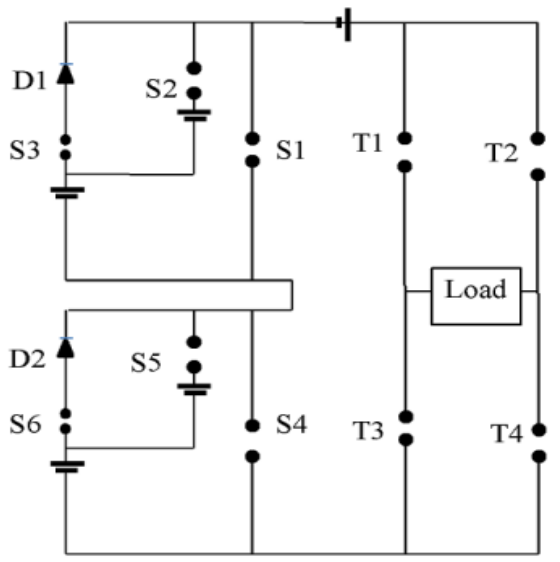

Fig. 1: Proposed 11 level of HCMLI

In figure1 two basic modules are connected in series to create output levels from which five positive output level are generated and remaining negative and zero level are generated with the help of H-bridge. Table 1 shows the switching state of 11 levels of symmetric HCMLI. In Generalize structure if $b$ is the total number of basic module then the $\mathrm{N}$ level $=4 \mathrm{~b}+3$ is numbers of levels we can get at the output and for achieving these output levels NDC $=2 b+1$ numbers of DC sources and NIGBTs $=3 \mathrm{~b}+4$ numbers of IGBTs are needed. Maximum output voltages is

$\mathrm{V}_{\mathrm{o}} \max =(2 \mathrm{~b}+1) \mathrm{V}_{\mathrm{dc}}$

Table 1. Switching state of 11 level of HCMLI

\begin{tabular}{|c|c|c|c|c|c|c|c|c|c|c|c|c|c|}
\hline $\mathbf{N}$ & $\begin{array}{c}\text { OUT } \\
\text { PUT } \\
\text { VOL } \\
\text { TAG } \\
\text { E }\end{array}$ & $\begin{array}{l}\text { D } \\
1\end{array}$ & $\begin{array}{c}\text { D } \\
2\end{array}$ & $\begin{array}{l}S \\
1\end{array}$ & $\begin{array}{l}S \\
2\end{array}$ & $\begin{array}{l}S \\
3\end{array}$ & $\begin{array}{l}S \\
4\end{array}$ & $\begin{array}{l}S \\
5\end{array}$ & $\begin{array}{l}S \\
6\end{array}$ & $\begin{array}{l}\mathbf{T} \\
\mathbf{1}\end{array}$ & $\begin{array}{l}T \\
2\end{array}$ & $\begin{array}{l}\mathbf{T} \\
\mathbf{3}\end{array}$ & \\
\hline 1. & $\begin{array}{c}+1 \mathrm{Vd} \\
\mathrm{c}\end{array}$ & $\begin{array}{l}\mathrm{O} \\
\mathrm{F} \\
\mathrm{F}\end{array}$ & $\begin{array}{l}\mathrm{O} \\
\mathrm{F} \\
\mathrm{F}\end{array}$ & 1 & 0 & 0 & 1 & 0 & 0 & 1 & 0 & 0 & 1 \\
\hline 2. & $\begin{array}{c}+2 \mathrm{Vd} \\
\mathrm{c}\end{array}$ & $\begin{array}{l}\mathrm{O} \\
\mathrm{N}\end{array}$ & $\begin{array}{l}\mathrm{O} \\
\mathrm{F} \\
\mathrm{F}\end{array}$ & 0 & 0 & 1 & 1 & 0 & 0 & 1 & 0 & 0 & 1 \\
\hline 3. & $\begin{array}{c}+3 \mathrm{Vd} \\
\mathrm{c}\end{array}$ & $\begin{array}{l}\mathrm{O} \\
\mathrm{F} \\
\mathrm{F}\end{array}$ & $\begin{array}{l}\mathrm{O} \\
\mathrm{F} \\
\mathrm{F}\end{array}$ & 0 & 1 & 0 & 1 & 0 & 0 & 1 & 0 & 0 & 1 \\
\hline
\end{tabular}

\begin{tabular}{|c|c|c|c|c|c|c|c|c|c|c|c|c|c|}
\hline 4. & $\begin{array}{c}+4 \mathrm{Vd} \\
\mathrm{c}\end{array}$ & $\begin{array}{l}\mathrm{O} \\
\mathrm{F} \\
\mathrm{F}\end{array}$ & $\begin{array}{l}\mathrm{O} \\
\mathrm{N}\end{array}$ & 0 & 1 & 0 & 0 & 0 & 1 & 1 & 0 & 0 & 1 \\
\hline 5. & $\begin{array}{c}+5 \mathrm{Vd} \\
\mathrm{c}\end{array}$ & $\begin{array}{l}\mathrm{O} \\
\mathrm{F} \\
\mathrm{F}\end{array}$ & $\begin{array}{l}\mathrm{O} \\
\mathrm{F} \\
\mathrm{F}\end{array}$ & 0 & 1 & 0 & 0 & 1 & 0 & 1 & 0 & 0 & 1 \\
\hline 6. & $0 \mathrm{Vdc}$ & $\begin{array}{l}\mathrm{O} \\
\mathrm{F} \\
\mathrm{F}\end{array}$ & $\begin{array}{l}\mathrm{O} \\
\mathrm{F} \\
\mathrm{F}\end{array}$ & 0 & 0 & 0 & 0 & 0 & 0 & 1 & 1 & 0 & 0 \\
\hline 7. & $-1 \mathrm{Vdc}$ & $\begin{array}{l}\mathrm{O} \\
\mathrm{F} \\
\mathrm{F}\end{array}$ & $\begin{array}{l}\mathrm{O} \\
\mathrm{F} \\
\mathrm{F}\end{array}$ & 1 & 0 & 0 & 1 & 0 & 0 & 0 & 1 & 1 & 0 \\
\hline 8. & $-2 \mathrm{Vdc}$ & $\begin{array}{l}\mathrm{O} \\
\mathrm{N}\end{array}$ & $\begin{array}{l}\mathrm{O} \\
\mathrm{F} \\
\mathrm{F}\end{array}$ & 0 & 0 & 1 & 1 & 0 & 0 & 0 & 1 & 1 & 0 \\
\hline 9. & $-3 \mathrm{Vdc}$ & $\begin{array}{l}\mathrm{O} \\
\mathrm{F} \\
\mathrm{F}\end{array}$ & $\begin{array}{l}\mathrm{O} \\
\mathrm{F} \\
\mathrm{F}\end{array}$ & 0 & 1 & 0 & 1 & 0 & 0 & 0 & 1 & 1 & 0 \\
\hline $\begin{array}{l}1 \\
0 .\end{array}$ & $-4 \mathrm{Vdc}$ & $\begin{array}{l}\mathrm{O} \\
\mathrm{F} \\
\mathrm{F}\end{array}$ & $\begin{array}{l}\mathrm{O} \\
\mathrm{F} \\
\mathrm{F}\end{array}$ & 0 & 1 & 0 & 0 & 0 & 1 & 0 & 1 & 1 & 0 \\
\hline $\begin{array}{l}1 \\
1 .\end{array}$ & $-5 \mathrm{Vdc}$ & $\begin{array}{l}\mathrm{O} \\
\mathrm{F} \\
\mathrm{F}\end{array}$ & $\begin{array}{l}\mathrm{O} \\
\mathrm{F} \\
\mathrm{F}\end{array}$ & 0 & 1 & 0 & 0 & 1 & 0 & 0 & 1 & 1 & 0 \\
\hline
\end{tabular}

\section{MODULATION METHOD}

Normally multicarrier PWM is used for triggering of the switches in inverter. In the given circuit carrier signals are arranged in POD (phase opposition disposition) manner. Sine wave is used as the modulating signal and compared with the carrier signal to generate switching signal for the proposed HCMLI. Figure 2 shows the POD modulation technique.

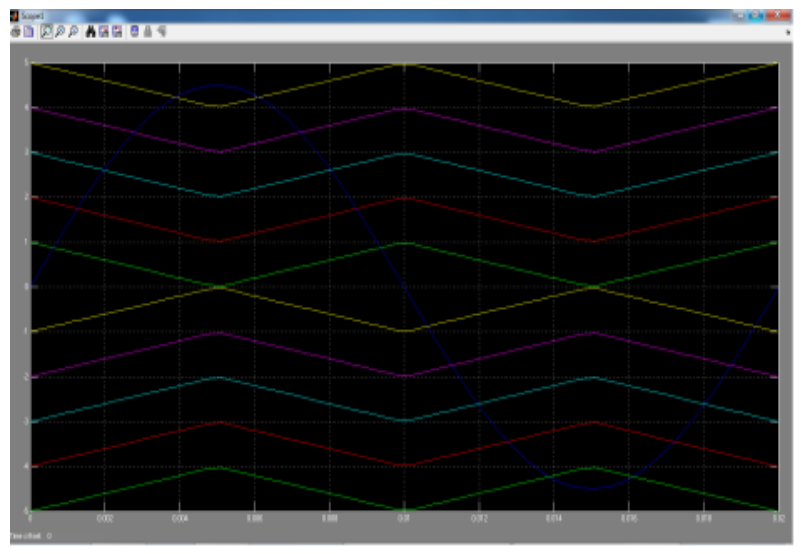

Fig. 2: POD Modulation Technique.

\subsection{Dynamic Voltage Restorer}

Dynamic Voltage Restorer (DVR) is a power electronics based custom power device that detects voltage sags/swells and produces a corresponding compensation voltage for injection in series to the distribution supply voltage, so that the voltage at a sensitive/ critical load is within certain limits [9]. Dynamic voltage restorer (DVR) is the most suitable and economical solution to compensate for voltage sags. In fact, the DVR is a series connected voltage source inverter (VSI). It generates compensation voltage which is added to the grid voltage usually through an injection transformer. 


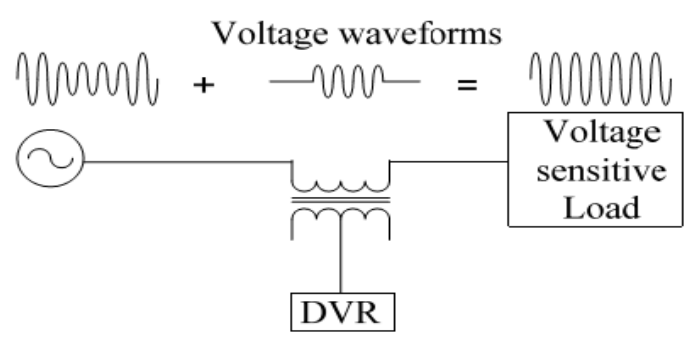

Fig. 3: Simple power system with a DVR

In this way, the voltage on the sensitive load remains almost unchanged [14] Fig. 4 shows the block diagram of test system. A Fuzzy logic controller (FLC) is implemented in DVR to response very fast on the request from abruptly changing reference signals. To design fuzzy FLC evaluating 49 linguistic rules process these errors. The output voltage signal is sensed and compared with reference signal. The comparative result is send to fuzzy controller and it generates PWM inverter signals [12-13]. Table 2 summarizes the DVR system parameters.

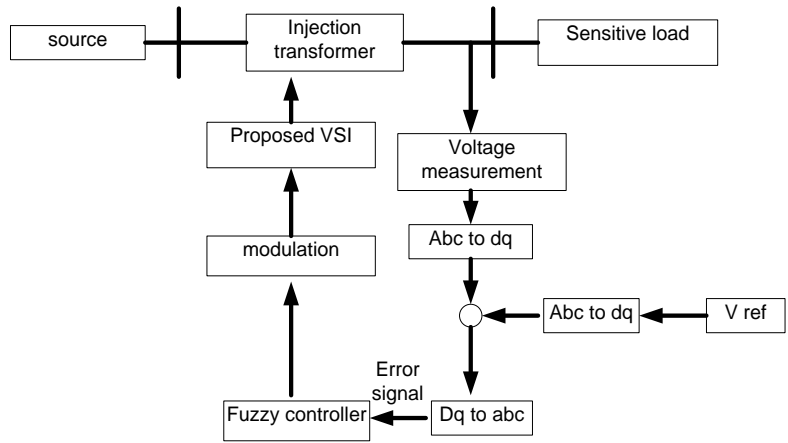

Fig.4: Block diagram of a DVR connected to sensitive load

Table 2. System parameters

\begin{tabular}{|c|c|c|c|}
\hline Parameter & Value & Parameter & Value \\
\hline Nominal Load voltage & $400 \mathrm{~V}$ & $\begin{array}{c}\text { Nominal } \\
\text { frequency }\end{array}$ & $50 \mathrm{~Hz}$ \\
\hline
\end{tabular}

\begin{tabular}{|c|c|c|c|}
\hline $\begin{array}{c}\text { No. of Dc Voltage source } \\
\text { in any phase }\end{array}$ & 5 & No. of levels & 11 \\
\hline No of IGBT in Inverter & 10 & Source Voltage & $11 \mathrm{KV}$ \\
\hline
\end{tabular}

\subsection{Fuzzy Logic Controller}

In fuzzy logic, basic control is determined by a set of linguistic rules which are determined by the system. Since numerical variables are converted into linguistic variables, mathematical modeling of the system is not required.

The fuzzy logic control fig. 5 is being proposed for controlling the inverter action on DVR. The fuzzy logic controller has two real time inputs measured at every sample time, named error (e) and error rate (de) and one output named actuating signal for each phase. The input signals are fuzzified and represented in fuzzy set notations as membership functions. The defined 'IF-THEN' rules produce output (actuating) signal and these signals are defuzzified to analog control signals for comparing with a carrier signal to control PWM inverter.

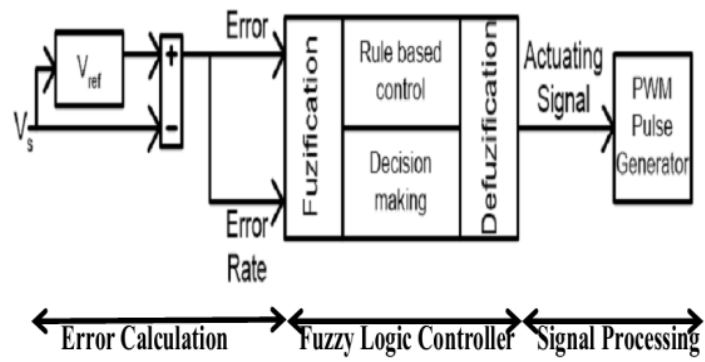

Fig. 5: Fuzzy Controller

\section{SIMULATION RESULTS}

All simulation of proposed work is done by MATLAB/ SIMULINK. SIMULINK diagram of open loop system for voltage Sag is shown in fig. 6, and SIMULINK diagram of open loop system for voltage Swell is shown in fig. 8. Voltage sag created at 0.4 to $0.6 \mathrm{sec}$ and it is for approx. $0.2 \mathrm{sec}$ as shown in figure 7(a). It also compensated at $0.4 \mathrm{sec}$. and inverter injected voltage is shown in figure 7(b), through which load voltage maintain its nominal value as shown in fig. 7(c).

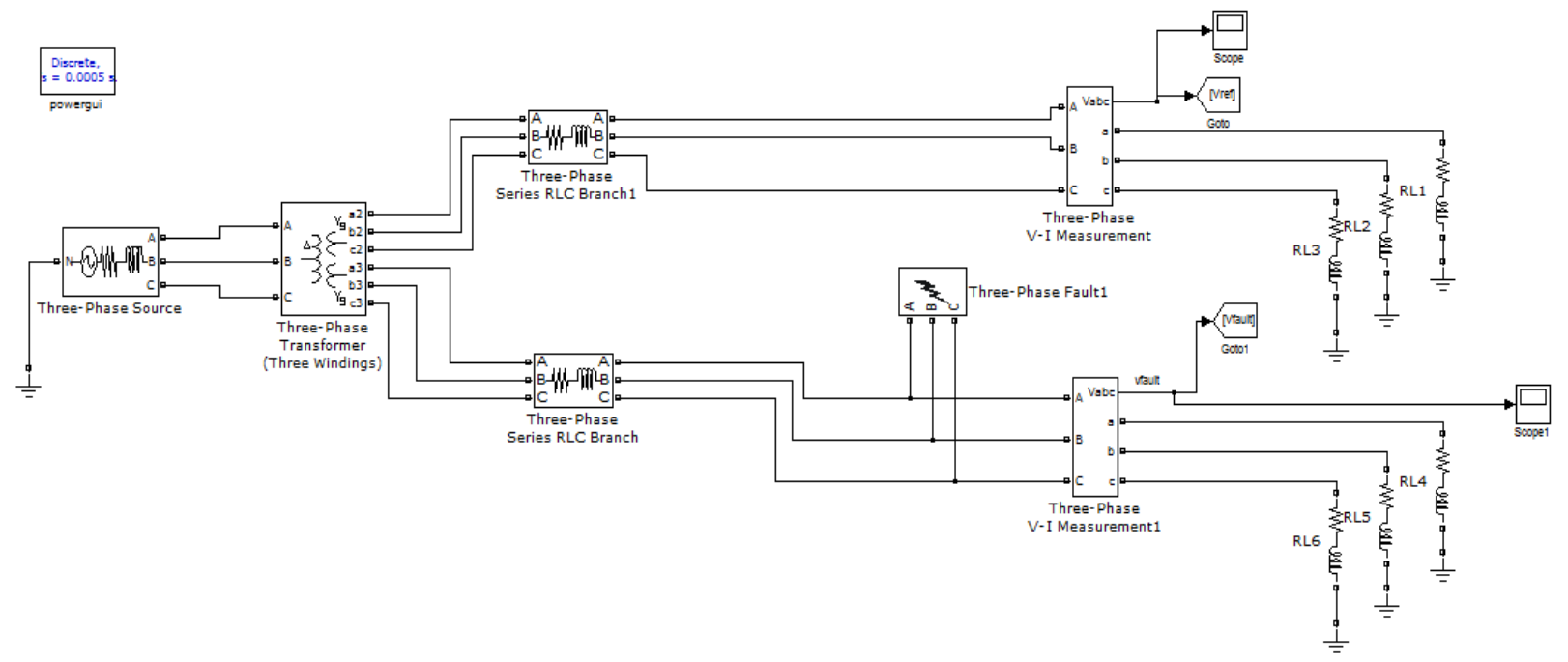

Fig. 6: SIMULINK diagram of open loop system for voltage Sag 


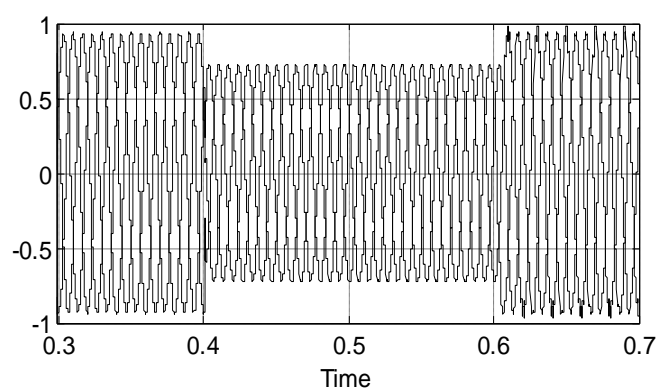

Fig. 7(a): Supply voltage in (pu)

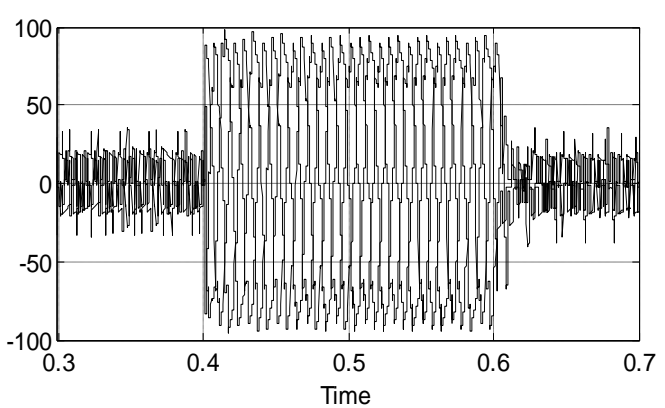

Fig. 7(b): DVR injected voltage

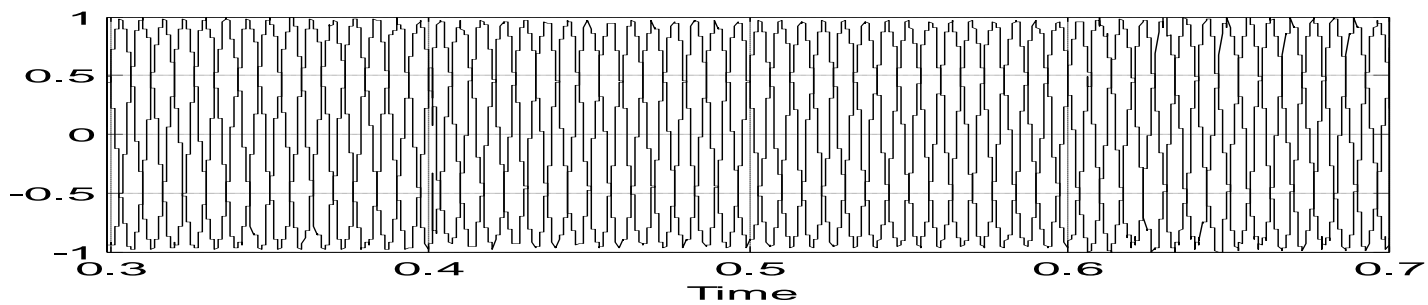

Fig. 7(c): Compensated load voltage in (pu)

Voltage swell is generated at 0.2 by using SLG(single line to ground fault) fault at phase A. swell duration is almost $0.2 \mathrm{sec}$ and it is cleared at $0.4 \mathrm{sec}$. fig.9(a) shows the swelled supply voltage and fig. 9(b) shows the compensated load voltage.

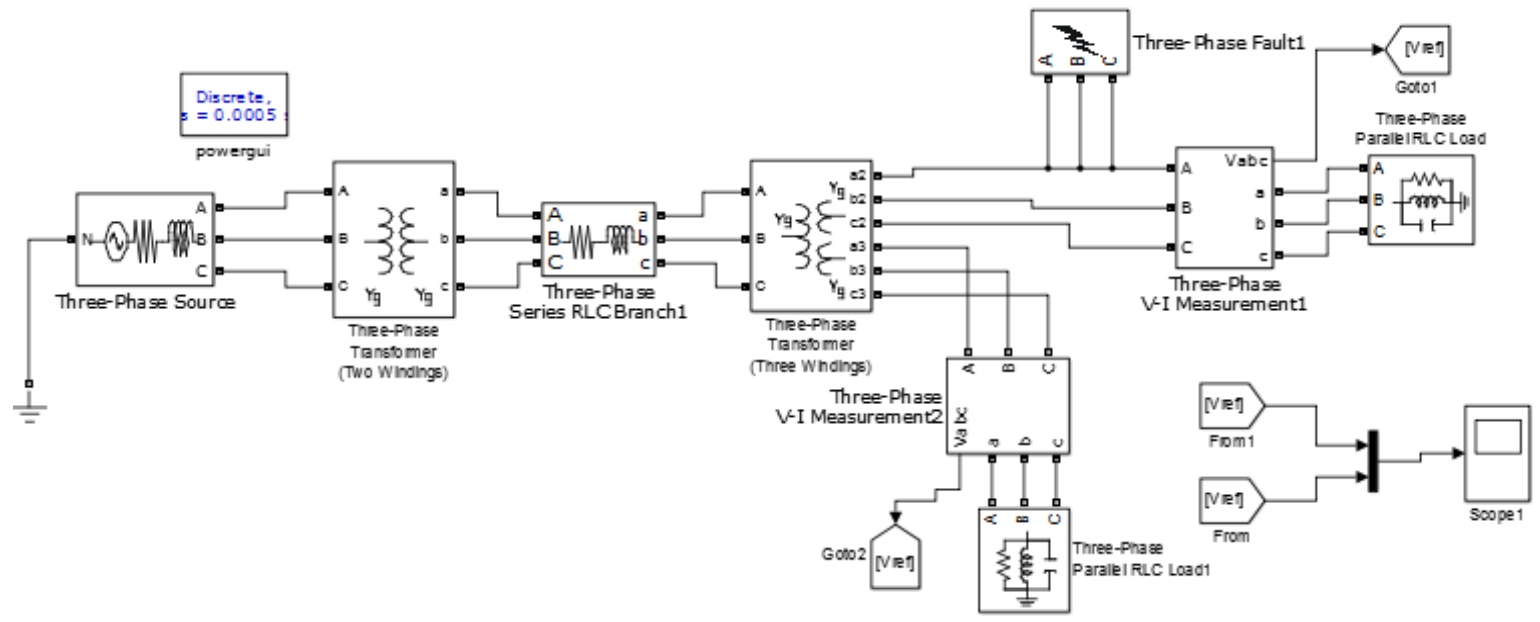

Fig.8: SIMULINK diagram of open loop system for voltage swell

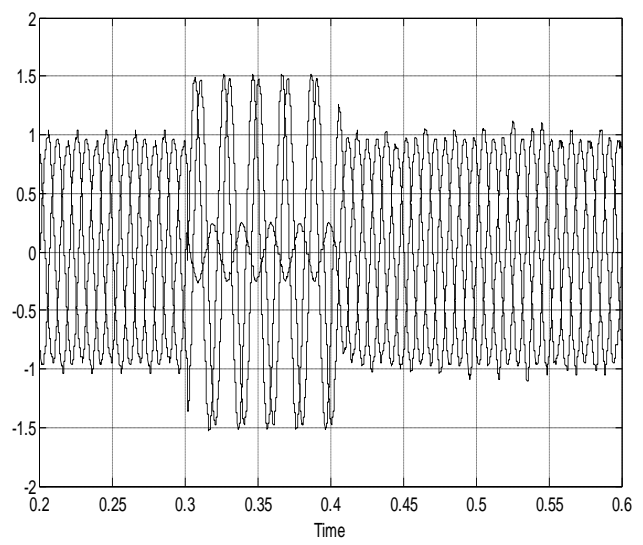

Fig 9(a): Supply voltage in (pu)

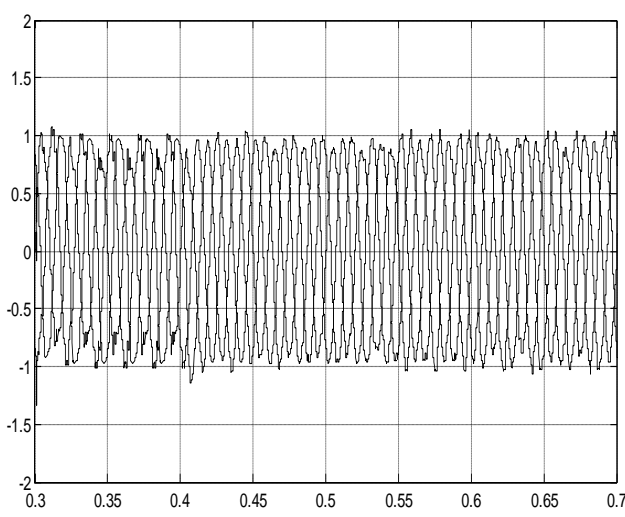

Fig 9(b): Compensated load voltage in (pu) 


\subsection{DVR With New Hybrid Cascade Multilevel Inverter}

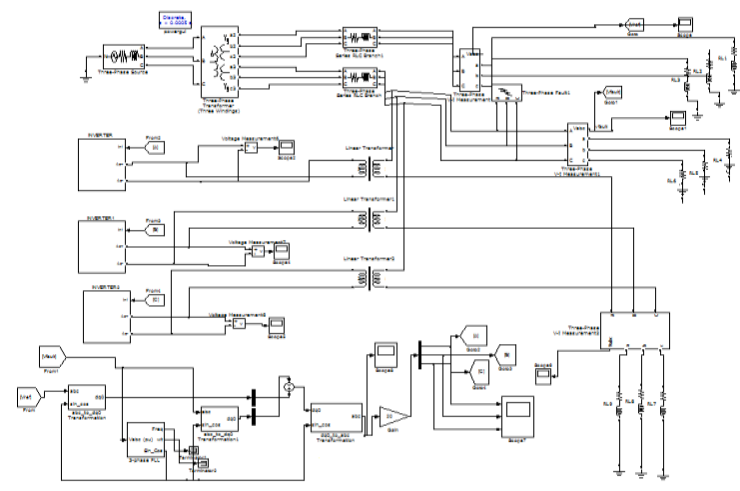

Fig 10: DVR with new hybrid cascade multilevel inverter

Fig.10 shows the DVR with new hybrid cascade multilevel inverter and the dq detection Technique has been used.

\subsection{DVR with New Hybrid Cascade Multilevel Inverter and Fuzzy Controller}

Fig.11shows the DVR with new hybrid cascade multilevel inverter with fuzzy controller has been used with a dq0 detection Technique.
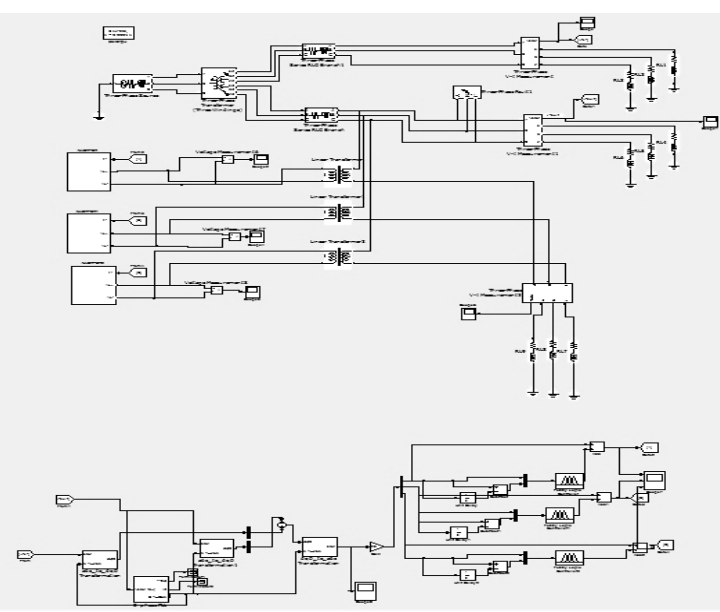

Fig 11: DVR with new hybrid cascade multilevel inverter and fuzzy controller

\subsection{Output Waveform of DVR With Fuzzy Logic Controller}

The following fig.12 represents the output response of DVR with Fuzzy logic controller for voltage sag and it is compensated in less than $0.2 \mathrm{sec}$.

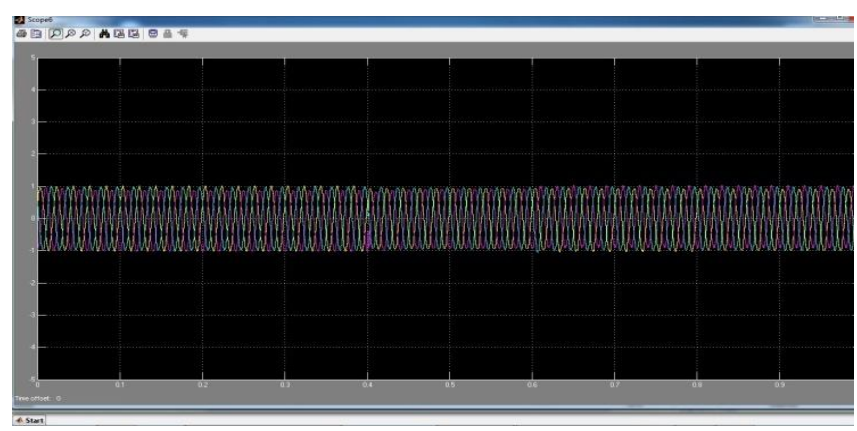

Fig. 12: DVR compensated load voltage at load using fuzzy logic controller.

\subsection{Comparison of THD for DVR and DVR with Fuzzy Control}

Table. 3 shows the comparison of THD values for open loop DVR and DVR with fuzzy control at each phase of load voltage.

Table 3. Comparison of DVR and DVR with fuzzy controller

\begin{tabular}{|c|c|c|}
\hline $\begin{array}{c}\text { THD at each } \\
\text { Phase }\end{array}$ & DVR & $\begin{array}{c}\text { DVR WITH FUZZY } \\
\text { CONTROL }\end{array}$ \\
\hline $\mathrm{A}$ & $1.73 \%$ & $1.61 \%$ \\
\hline $\mathrm{B}$ & $1.42 \%$ & $0.90 \%$ \\
\hline $\mathrm{C}$ & $1.43 \%$ & $1.32 \%$ \\
\hline
\end{tabular}

\section{CONCLUSION}

Now-a-days, reliability and quality of electric power is one of the most researched subject matter in power industry. Out of several power quality issues problems two power quality problems that have been identified to be of major concern to the customers are voltage sags / swells and harmonics. This work focuses fuzzy logic controlled DVR using a 11- level of Hybrid Cascade Multilevel to compensate voltage sag and voltage swell. It is found from the results that proposed multilevel inverter is able to compensate voltage sag and voltage swell within limiting time.

\section{REFERENCES}

[1] Gonzalez, Sergio A., and María I. Valla. "A DVR built with a 5-level cascade asymmetric multilevel converter." Industrial Technology (ICIT), 2013 IEEE International Conference on. IEEE, 2013

[2] Ankit Pandey, Rajlakshmi " Dynamic Voltage Restorer and Its application at LV \& MV Level" International Journal of Scientific \& Engineering Research, Volume 4, Issue 6, June-2013 ISSN 2229-5518.

[3] Prasad, K. N. V., et al. "Realization of cascaded H-bridge 5-Level multilevel inverter as Dynamic Voltage Restorer. "Computer Communication and Informatics (ICCCI), 2013 International Conference on. IEEE, 2013,1-6

[4] Bhumkittipich, Krischonme, Wuthikrai Chankhamrian, and Nadarajah Mithulananthan. "Application of Threelevel Diode-clamped Converter on 10kW Distribution Voltage Restorer." Energy Procedia 34 (2013): 116-129.

[5] Banaei, M. R., and E. Salary. "New multilevel inverter with reduction of switches and gate driver." Energy Conversion and Management 52.2 (2011): 1129-1136.

[6] Babaei, E., et al. "Reduction of dc voltage sources and switches in asymmetrical multilevel converters using a novel topology." Electric Power Systems Research 77.8 (2007): 1073-1085.

[7] Babaei, Ebrahim, et al. "Cascaded multilevel inverter using sub-multilevel cells."Electric Power Systems Research 96 (2013): 101-110.

[8] Ahmed, Rokan Ali, S. Mekhilef, and Hew Wooi Ping. " New multilevel inverter topology with minimum number of switches." TENCON 2010-2010 IEEE Region 10 Conference. IEEE, 2010.1862-1867 
[9] Ezoji, H., et al. "A new control method for Dynamic Voltage Restorer with asymmetrical inverter legs based on fuzzy logic controller." Simulation Modeling Practice and Theory 18.6 (2010): 806-819.

[10] Mohamad Reza Banaei , Ali Reza et. al "DVR based Cascaded Multilevel Z-Source Inverter" 2010 conference of power and energy(PEcon2010),nov 29-Dec 12010 , Kualalumpur,Malaysia,51-56

[11] Salimin, Rahmatul Hidayah, and M. S. A. Rahim. " Simulation Analysis of DVR performance for voltage sag mitigation." Power Engineering and Optimization Conference (PEOCO), 2011 5th International. IEEE, 2011.

[12] Ramasamy, M., and S. Thangavel. "Experimental verification of PV based Dynamic Voltage Restorer (PVDVR) with significant energy conservation."
International Journal of Electrical Power \& Energy Systems 49 (2013): 296-307.

[13] B.Panda, A.K. mahapatra, et al "Fuzzy logic controller based dynamic voltage restorer for mitigation of voltage sag" vol.3 No 2 Feb 2011, International Journal of Engineering Science and Technology(IJEST),996-1007.

[14] Ebrahim Babaei, Mohammmad Farhadi, et. Al "Dynamic voltage restorer based on multilevel inverter with adjustable dc-link voltage"” IET power electronics 2014, vol 7, Issue 3, 576-590.

[15] E. Babei, M. Farhadi et al "Compensation of voltage disturbances in distribution systems using single phase dynamic voltage restorer" Electric power system research 2010,1413-142 